\title{
Influence of Organic Matter on Gas-Bearing Properties and Analysis of Sedimentary Mechanism of Organic Matter Enrichment: A Case Study on the Yangtze Region of Southern China during the Early Cambrian
}

\author{
Qinyu Li, ${ }^{1,2}$ Kun Zhang $\left(\mathbb{D},{ }^{3,4,5,6}\right.$ Lin Wei $\mathbb{D},{ }^{7}$ Dahai Wang $\mathbb{D},{ }^{2}$ Zhiyuan Chen, ${ }^{8}$ \\ Xiangdong Yin, ${ }^{3,4,9}$ Fengli Han, ${ }^{3,4}$ Pei Liu, ${ }^{3,4}$ Liangyi Tang, ${ }^{3,4}$ and Xuejiao Yuan ${ }^{3,4}$ \\ ${ }^{1}$ School of Economics and Management, Chengdu Sport University, Chengdu 610041, China \\ ${ }^{2}$ PetroChina Changqing Oilfield Exploration and Development Research Institute, Xi'an 710018, China \\ ${ }^{3}$ School of Geoscience and Technology, Southwest Petroleum University, Chengdu 610500, China \\ ${ }^{4}$ State Key Laboratory of Oil and Gas Reservoir Geology and Exploitation, Southwest Petroleum University, \\ Chengdu 610500, China \\ ${ }^{5}$ Key Laboratory of Tectonics and Petroleum Resources (China University of Geosciences), Ministry of Education, \\ Wuhan 430074, China \\ ${ }^{6}$ Energy and Geoscience Institute, University of Utah, Salt Lake City, UT 84108, USA \\ ${ }^{7}$ School of Energy Resources, China University of Geosciences (Beijing), Beijing 100083, China \\ ${ }^{8}$ CNPC Managers Training Institute, Beijing 100096, China \\ ${ }^{9}$ State Key Laboratory of Petroleum Resources and Prospecting, China University of Petroleum, Beijing 102249, China \\ Correspondence should be addressed to Kun Zhang; shandongzhangkun@126.com and Lin Wei; linwei@cugb.edu.cn
}

Received 8 November 2021; Accepted 24 December 2021; Published 4 February 2022

Academic Editor: Mohammed Fattah

Copyright (c) 2022 Qinyu Li et al. This is an open access article distributed under the Creative Commons Attribution License, which permits unrestricted use, distribution, and reproduction in any medium, provided the original work is properly cited.

Shale gas exploration requires studies on the enrichment mechanism of sedimentary organic matter. The Lower Cambrian shale is taken as a study object to analyze the effect of organic matter on gas content using TOC content and porosity analyses, isothermal adsorption experiments, and FIB-HIM scanning electron microscopy observations. Then, we selected typical wells to determine the presence of excessive silica in the siliceous minerals by quantitative calculations. Besides, we analyzed the genesis of excessive siliceous minerals using elements including $\mathrm{Al}, \mathrm{Fe}$, and $\mathrm{Mn}$, thus speculating the controlling factors of the redox environment and biological productivity. Results show that total organic carbon content controls the content of free and adsorbed gas, while shale gas mainly exists in organic pores and is developed in large numbers and with high roundness, showing the characteristics of "small pores inside big pores." In the Lower Yangtze region during the Early Cambrian, the excessive siliceous minerals were of hydrothermal origin, and there were frequent hydrothermal activities due to its closeness to plate boundaries. These activities can intensify the reducibility of the waterbody's bottom and improve the biological productivity on its surface, resulting in the enrichment of this matter. Most excessive silicon in this region is biogenic, while only a small part is of hydrothermal and biogenic mixed origin. The enclosed waterbody of the Upper Yangtze region was far from plate boundaries and close to the semiclosed "gulf," resulting in its delamination. The waterbody's surface was abundant with oxygen, thus increasing the biological productivity, while the high reducibility at the waterbody's bottom was conducive to preserving sedimentary organic matter. 


\section{Introduction}

Since 2010, shale gas exploration in Sichuan and its surrounding areas has achieved great success with exploration concepts and technologies. PetroChina and Sinopec Group have conducted commercial exploitation in Weiyuan, Changning, Zhaotong, Fushun-Yongchuan, Fuling, Dingshan, Luzhou, Qijiang, Taiyang-Dazhai, Nanchuan, and other blocks [1-4]. Organic matter serves as the material basis on which shales generate hydrocarbon, and it provides shale gas with the main reservoir space and seepage channels. Open space in shale gas development areas can be used to build nature experience parks and caravan camps for hiking, trekking, sports tourism, outdoor sports, and other sporting events.

Exploring the enrichment pattern of sedimentary organic matter is becoming increasingly significant as the total organic carbon (TOC) content in shale is influenced by thermal evolution degrees and abundance of this matter. Many studies using different approaches have been conducted to analyze the mechanism [5-9]. Xia et al. utilized trace and rare Earth elements to prove that ascending currents facilitated organic matter enrichment. By studying strata of the Lower Cambrian Niutitang Formation (LCNF) in the upper reaches of the Yangtze region, southeast of Chongqing, they found that the formation was influenced by deep-sea hydrothermal fluids carried by oceanic currents [10]. After studying the lower boundary of the Cambrian series in the upper reaches of the Yangtze region, Zhang et al. concluded that the shales rich in organics in the shelf area are affected by seawater redox conditions. Organic matter can be better preserved in redox environments and, in the slope-basin area, its content in the organic-rich shales is mainly controlled by primary biological productivity. If organic matter is deposited under the same condition, this area is more abundant in organic matter than that in the shelf area [11]. Zhang et al. pointed out that shales were sediments of redox water conditions in the anoxic deepsea environments on passive continental margins. Simultaneously, these shales were affected by ascending currents or hot water to a certain extent [12]. Findings by Qiu et al. show that volcanic ash has a relatively small influence on ocean regions with high productivity and promotes the organic matter's enrichment [13]. However, sedimentary waterbody's redox conditions (the change from rich oxygen and lean oxygen to hypoxia) are related closely to organic matter content and dominant in the enrichment of organic matter [14-17].

Recent technological advances and massive shale gas exploration have provided unprecedented data for studying the effect of organic matter on gas content as well as the enrichment pattern of organic matter sediments. Isothermal sorption experiments and FIB-HIM observations have provided new experimental methods for studying the effect of organic matter on gas content. Previous studies were mainly conducted on siliceous mineral genesis. The origin of siliceous minerals can be determined by Al-Fe-Mn triangular diagram that is proposed by Wedepohl, Holdaway and Clayton, Adachi et al., and Yamamoto [18-21]. Combining the two methods, this paper first quantitatively calculated whether there is excessive silicon in siliceous minerals in shales and then figured out its content. Furthermore, the origin of excess silicon was discovered, and the enrichment pattern of organic matter sediments was dissected. The organic matter sediments in the lower and upper reaches of the Yangtze region during the Early Cambrian are compared in this paper.

\section{Geological Settings}

2.1. Characteristics of Sedimentation and Strata. As researched previously [22-25], the Yangtze region consisted of paleocontinents, shallow deep shelves, continental slopes, and oceanic basins extending from northwest to southeast during the Early Cambrian. Correspondingly, the Cathaysian Plate was composed of the above from southeast to northwest, as shown in Figure 1. The waterbody is the deepest at the boundary of two plates and gets shallower in the direction of the ancient land on each side.

During the Early Cambrian period, a series of strata were vastly sedimented in both plates. To differentiate between them in the vast land, they are named variously (e.g., Wangyinpu Formation and Niutitang Formation in the lower course of Yangtze region and in its southeast part, resp.) in different areas. The target strata for exploring shale gas subsea in China are dark grey-black siliceous shales sediments rich in organics during the Early Cambrian period.

2.2. Tectonic Characteristics. This study involves the Lower and Upper Yangtze regions. Previous studies showed that, in the early Mesoproterozoic [24-26], the ocean basin divided South China's primitive continental crust into the Yangtze and Cathaysian Plates. Thereinto, the former refers to the Cratonic Basin. The two plates in tension experienced a massive transgression during the Early Cambrian period, depositing shales rich in organics that covered almost both plates. Subsequently, the waterbody grew shallower as the lithology transformed from fine and silty shales into siltstones, sandstones, and other coarse clastic rocks.

In the Ordovician, the waterbody continued becoming shallower due to the extrusion and collision of the Cathaysian Plate, and the sedimentary system transitioned from clastic rocks into carbonate rocks. However, a largescale transgression occurred in the Upper Ordovician-Lower Silurian, causing this system to revert to clastic rocks, with organic-rich shales sedimented. The oceanic basin of both plates collided with the Yangtze Plate during the CambrianSilurian. When the Silurian period ended, the two plates merged to form the South China Plate.

\section{Samples, Experiments, and Data Sources}

We herein adopted samples taken from two wells and two sections, in which Well TX-1, Guizhou Taozichong outcrops, and Zhalagou outcrops were located in the upper reaches of the Yangtze region, and Well JY-2 was located in its lower reaches. Well TX-1 belongs to the Cen'gong shale gas block, and Well JY-2 belongs to the Xiuwu Basin. Well TX-1, Guizhou Taozichong outcrops, and Zhalagou outcrops are located near Guiyang in the Upper Yangtze region. 


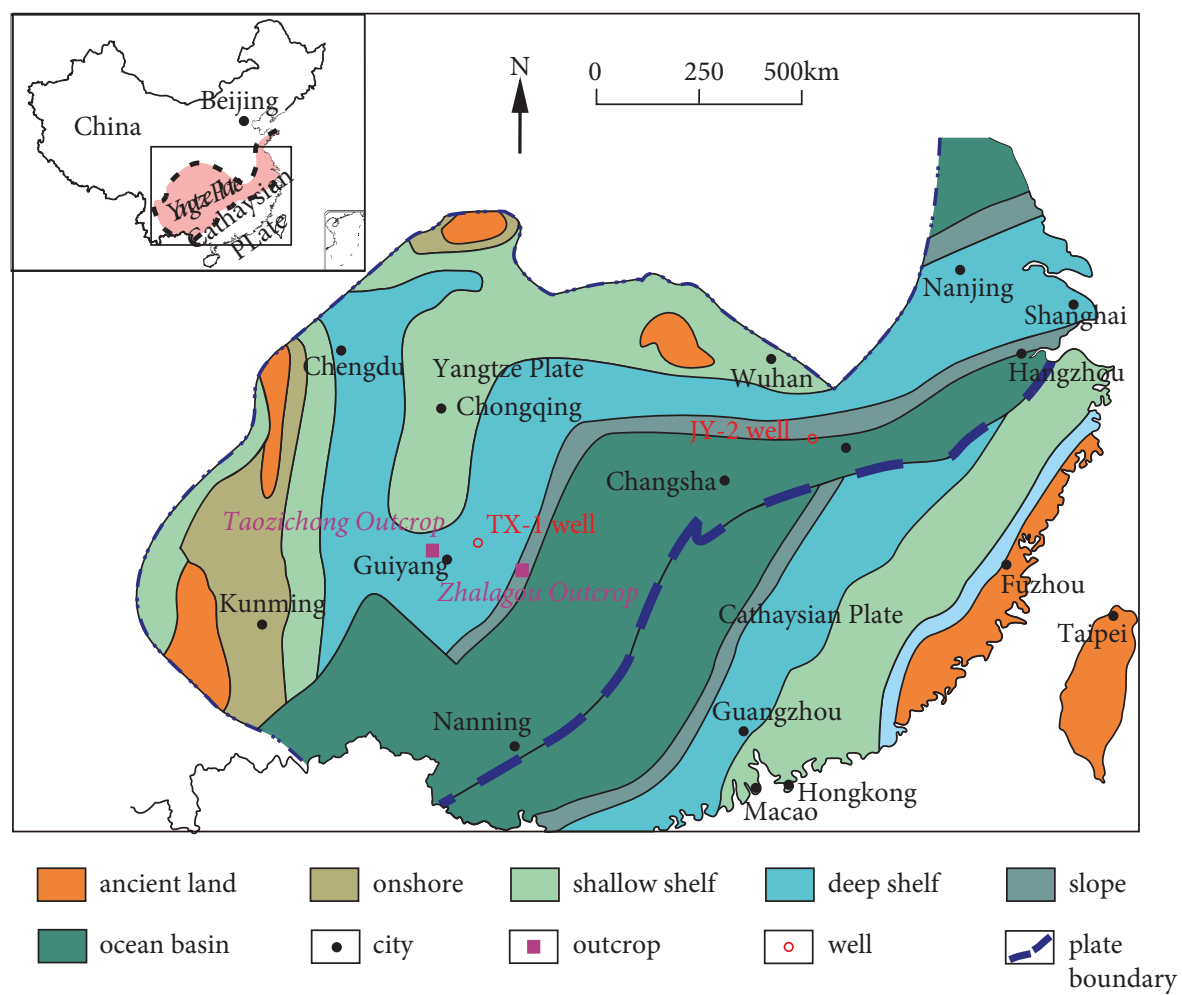

Figure 1: Sedimentary features of Early Cambrian South China (adapted from [17-20]).

Due to the relatively small variation of marine shales, this well and the two profiles are not far apart, so more data can be provided for the study of the organic matter enrichment mechanism of marine shales in the Upper Yangtze region.

Eighty key samples were collected from the LCNF's Well TX-1, among which 61 samples were analyzed using a Poro PDP-200 porosity tester for their shale porosity; 17 samples underwent isothermal adsorption experiment at $50^{\circ} \mathrm{C}$ using an isothermal adsorber model HPVA-200-4, and two samples were observed by FIB-HIM, that is, focused ion beam and helium ion microscopy, using a Zeiss Orion NanoFab. 75 and 61 core rock samples were taken from LCNF's Well JY-2 and LCNF's Well TX-1. A TOC analyzer (OG-2000V) was adopted to determine the TOC content of these samples. Besides, another 45 and 75 core samples were collected from the above wells, respectively. The elemental analyses for these samples, including $\mathrm{Al}, \mathrm{Fe}, \mathrm{Mn}, \mathrm{Ba}$, and $\mathrm{Mo}$, were conducted by the X-ray Fluorescence Analyzer (Axios-MAX).

Zhang et al. reported TOC content of 37 samples as well as the Mo test data from the LCNF of Taozichong outcrops and Zhalagou outcrops in Guizhou [25]. The log data of Si, $\mathrm{Al}, \mathrm{U}$, and Th for the two aforementioned wells were collected from Schlumberger, with a logging interval of $0.125 \mathrm{~m}$. Some data come from the literature of [27-31].

\section{Results and Discussion}

\subsection{Impacts of Organic Matter on Gas Content}

4.1.1. Relationship among TOC Content, Porosity, and Langmuir Volume. The Langmuir Volume $\left(\mathrm{m}^{3} / \mathrm{t}\right)$ represents the maximum sorption capacity and physically denotes the adsorbed shale gas content at a specific temperature when methane adsorption saturates. The free gas is mainly correlated with porosity. The relationships between Langmuir Volume/core porosity and TOC content are shown in Figures 2(a) and 2(b), respectively. According to this figure, both the Langmuir Volume and core porosity have strong correlations with the TOC content, showing that the TOC content controls both the absorbed gas content and the free gas content, which are found to mainly exist in the organic matter pores.

4.1.2. FIB-HIM Analysis of Organic Matter Pore Connectivity. The FIB-HIM images allow for the observation of pore interiors, resulting in a three-dimensional effect of a two-dimensional image. In the FIB-HIM images, as the molecular weight decreases, the greyscale composed by all shale materials increases, implying that the organic matter in the FIB-HIM images is lighter in color and has a lower greyscale than the inorganic minerals. According to Figures 3(a) and 3(b), the organic matter pores are well rounded and numerous, with a large number of tiny pores nested within large pores, which is similar to a honeycomb, providing them with excellent connectivity.

4.1.3. Significance of Conducting Analysis on the Sedimentary Mechanism of Organic Matter Enrichment. The aforementioned research shows that organic matter serves as both the material base for shale hydrocarbon generation and the main storage area and leakage channels for shale gas. The organic 


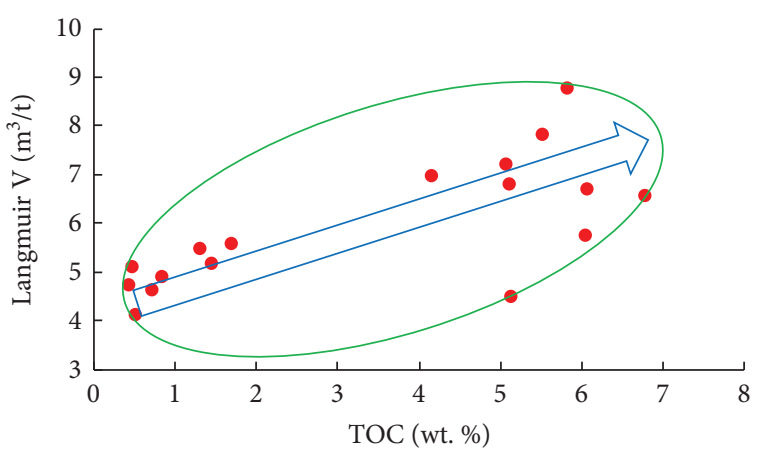

(a)

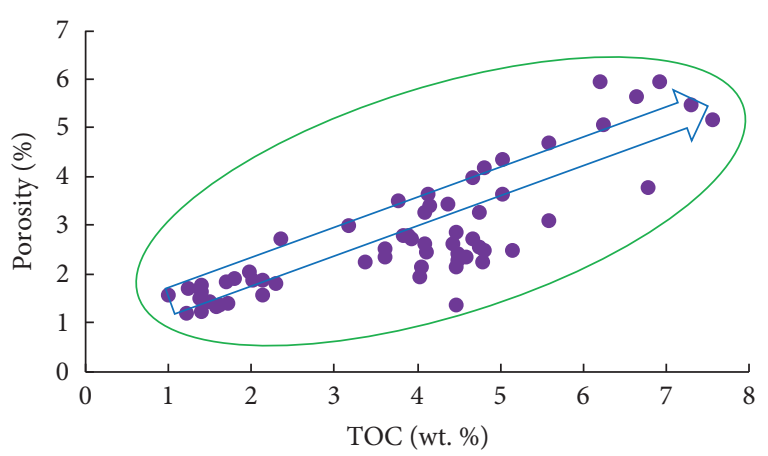

(b)

Figure 2: Relationship between Langmuir Volume and TOC content (a) and that between porosity and TOC content (b) for Well TX-1 of the Niutitang Formation in the Lower Cambrian. The well location is depicted in Figure 1.

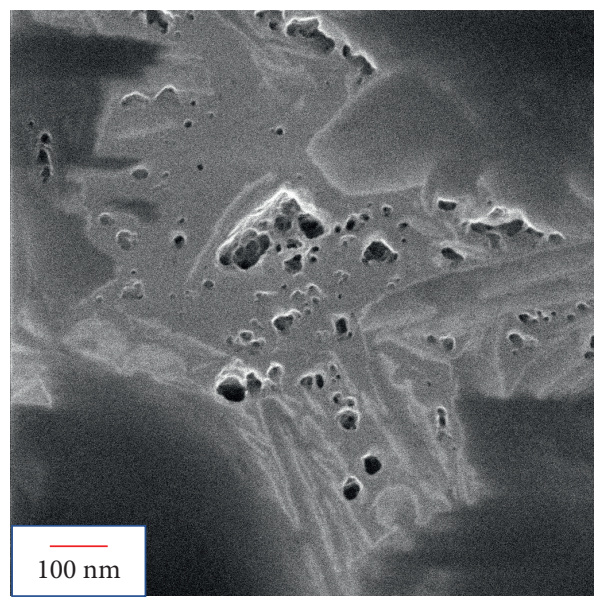

(a)

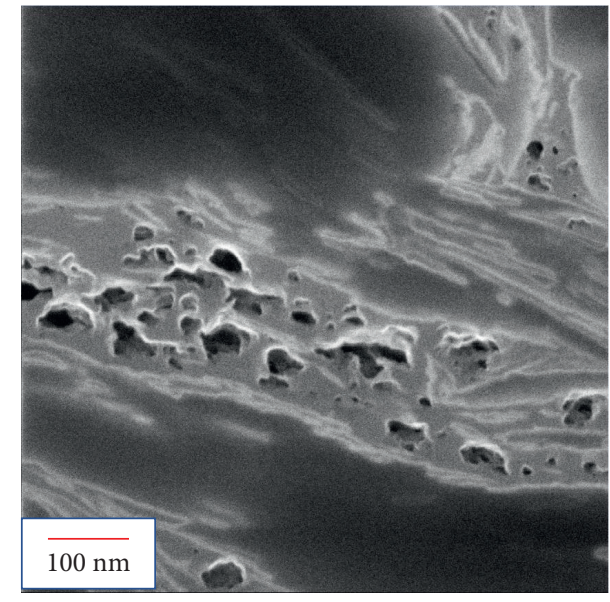

(b)

Figure 3: FIB-HIM images. (a) $1792 \mathrm{~m}$, Well TX-1, LCNF. (b) $1801 \mathrm{~m}$, Well TX-1, LCNF.

carbon (OC) content of modern shale is influenced by the abundance of primary organic matter sediments and the thermal evolution degree. When thermal evolution reaches a certain degree, the OC content of the modern shale is determined by the abundance of primary organic matter sediments. As a result, identifying factors that contribute to the abundance becomes crucial.

\subsection{Index Selection for Redox Conditions and Bioproductivity}

4.2.1. Selection of Redox Condition Indicators. A sedimentary condition is typically determined by elemental geochemical indexes. Jones and Manning analyzed the whole-rock samples and proposed that U/Th values reflect redox conditions of sedimentation. In general terms, A U/Th ratio exceeding 1.25 creates an anaerobic environment [32]; $\mathrm{U} / \mathrm{Th}=0.75-1.25$ produces an oxygen-deficient environment; and $\mathrm{U} / \mathrm{Th}$ less than 0.75 means an oxidative environment.

4.2.2. Selection of the Bioproductivity Indicators. The content of $\mathrm{Ba}$ and Mo each is widely adopted to demonstrate the paleooceanic productivity. The two elements originate from terrigenous sedimentation or biological action [33], and $\mathrm{Ba}$ that originates only from biotic sources is referred to as excess $\mathrm{Ba}\left(\mathrm{Ba}_{\mathrm{xs}}\right)$. The content is generally calculated by subtracting the terrigenous clastic Ba from the total content:

$$
\mathrm{Ba}_{\mathrm{xS}}=\text { Basample }-\mathrm{Al}_{\text {sample }}\left(\frac{\mathrm{Ba}}{\mathrm{Al}}\right)_{\text {PAAS }},
$$

where $\mathrm{Ba}_{\text {sample }}$ represents the total content of $\mathrm{Ba}$ and $\mathrm{Al}_{\text {sample }}$ represents that of $\mathrm{Al}$ in tested samples. PAAS refers to the standard Australian shale, and $(\mathrm{Ba} / \mathrm{Al})_{\mathrm{PAAS}}$ is the ratio of the two elements, namely, $7.7 \times 10^{-3}[34]$.

Similarly, Mo derived solely from the biological action is referred to as excess $\mathrm{Mo}\left(\mathrm{Mo}_{\mathrm{xs}}\right)$. The estimated content can be figured by subtracting terrigenous clastic Mo from the total content.

$$
\mathrm{Mo}_{\mathrm{XS}}=\mathrm{Mo}_{\text {sample }}-\mathrm{Al}_{\text {sample }}\left(\frac{\mathrm{Mo}}{\mathrm{Al}}\right)_{\text {PAAS }}
$$

where $\mathrm{Mo}_{\text {sample }}$ represents the total content of Mo and $\mathrm{Al}_{\text {sample }}$ represents that of Al. PAAS refers to the standard Australian shale, while $(\mathrm{Mo} / \mathrm{Al})_{\text {PAAS }}$ is $1.086 \times 10^{-5}$, representing the ratio between the two elements in the same shale [34]. 


\subsection{Analysis of Mechanism of Organic Matter Sediments in the Lower Cambrian Well JY-2}

4.3.1. Calculation and Source Analysis of Excessive Siliceous Mineral Content. Well JY-2 lies in the shale gas block, Xiuwu Basin, in the lower course of the Yangtze region. The target stratum is Lower Cambrian Wangyinpu Formation (LCWF). With the goal of analyzing the sedimentation mechanism of an organic matter accurately, this study introduced the excessive siliceous mineral content $\left(\mathrm{Si}_{\mathrm{ex}}\right)$ [35-39]. Silicon originates either from terrigenous clastic sedimentation in normal circumstances or from the hydrothermal and biogenic origins in special situations. $\mathrm{Si}_{\mathrm{ex}}$ represents the siliceous minerals that would otherwise be derived from the sedimentation above.

The formula hereunder is used for the calculation of its content:

$$
\mathrm{Si}_{\mathrm{ex}}=\mathrm{Si}_{\mathrm{s}}-\left[\left(\frac{\mathrm{Si}}{\mathrm{Al}}\right)_{\mathrm{bg}} \times \mathrm{Al}_{\mathrm{s}}\right],
$$

where $\mathrm{Si}_{\mathrm{s}}$ and $\mathrm{Al}_{\mathrm{s}}$ denote the content of $\mathrm{Si}$ and $\mathrm{Al}$ in samples, respectively. $(\mathrm{Si} / \mathrm{Al})_{\mathrm{bg}}$ or shale's average content is 3.11 [34].

The $\mathrm{Si}_{\text {ex }}$ content in Well JY-2 in the LCWF is calculated using the formula, and Figure 4 shows the result, indicating that the $\mathrm{Si}_{\mathrm{ex}}$ is contained in most segments of the Wangyinpu Formation. Thereinto, half of them show the content of $10 \%-20 \%$, while some show the value of $20 \%-30 \%$ or above.

The Al-Fe-Mn triangular graph, as put forward by Wedepohl, Holdaway and Clayton, Adachi et al., and Yamamoto, is used to identify whether the origin of siliceous minerals is hydrothermal or biogenic [18-21]. The test values of $\mathrm{Al}, \mathrm{Fe}$, and $\mathrm{Mn}$ in the segment containing $\mathrm{Si}_{\mathrm{ex}}$ in Well JY-2 are plotted on a triangular graph in this paper. According to Figure 5, these values are primarily distributed over the hydrothermal origin area, demonstrating that $\mathrm{Si}_{\mathrm{ex}}$ is formed due to this origin.

\subsubsection{Effect of Hydrothermal Activities on Enrichment of} Organic Matter Sediments. Previous studies have been carried out to study the closure of the waterbody in the Yangtze region, as shown in Figure 1. The results showed that the proximity of the Lower Cambrian Yangtze region to the open ocean basin led to weak closure of the waterbody, exerting a limited effect on sedimentary organic matter enrichment $[38,39]$. A great deal of silicon of hydrothermal origin formed in Well JY-2 is linked to the frequent tension activities on the Yangtze and Cathaysian Plates in the Lower Cambrian [18-21]. Its content demonstrates that the intensity of hydrothermal activities contributes to the presence of shale siliceous minerals. Furthermore, it influences the bioproductivity and the waterbody's redox conditions. Hence, the sedimentary organic matter abundance is influenced.

(1) Influence of Hydrothermal Activity on the Redox Environment. Sun et al. and Zhang et al. discovered that an anaerobic environment forms when the reduced acid hydrothermal fluids flow to the seafloor, helping to preserve organic matter [40-42]. The Lower Cambrian hydrothermal activities are well correlated with the water redox conditions in Xiuwu Basin. As shown in Figure 4, these activities frequently occur in Well JY-2 in the LCWF. In most cases, the $\mathrm{U} / \mathrm{Th}$ value exceeds 1.25 , indicating an anaerobic environment.

In the segments with high-intensity activities (LCWF's upper and lower areas), this value can range from 4 to 20 , indicating that the waterbody is highly reducible. However, it is 1.25-4 when it comes to the segments with a lower intensity (Wangyinpu Formation's bottom and middle areas).

(2) Impact of Hydrothermal Activity on Paleoproductivity. A general assumption is that paleoproductivity has a strong influence on hydrothermal activities. Halbach et al. discovered more organisms with a higher activity intensity in the waterbody when they are closer to the hydrothermal area in Fiji Basin, based on an analysis of this area [43]. Compared with the ordinary ocean surface, the order of magnitude is $1-3$ higher in this area.

Hydrothermal activities in Well JY-2 are also linked to the bioproductivity in the Lower Cambrian. Figure 4 depicts the frequent activities in the LCWF. The $\mathrm{Ba}_{\mathrm{xs}}$ content here is higher than that in the overlying LCGF strata or in the underlying Upper Sinian Piyuancun Formation (USPF) strata.

(3) Impact of Hydrothermal Activity on the Shale TOC Content. This activity intensity has the potential to influence the water redox environment and bioproductivity and thus control the TOC content of the current shale. According to Figure 4, this content is as high as $10 \%-15 \%$ in the segments with high-intensity activities (Wangyinpu Formation's top and upper and lower parts in the Lower Cambrian). However, it reduces to $0.5 \%-5.5 \%$ in the segments with a lower intensity (the bottom and middle part of Wangyinpu Formation).

\subsection{Analysis on Sedimentary Characteristics of Well TX-1 in the Lower Cambrian}

4.4.1. Calculation and Source Analysis of Si $i_{e x}$. Well TX-1 sits in the Cen'gong shale gas block, in the lower part of the Yangtze region. The LCNF is the target stratum. Similarly, the content of $\mathrm{Si}_{\mathrm{ex}}$ is obtained using the formula. The results are shown in Figure 6. It can be speculated that $\mathrm{Si}_{\mathrm{ex}}$ exists in Niutitang Formation, with content ranging from $10 \%$ to $20 \%$ in half of them and from $20 \%$ to $30 \%$ in others. Under certain circumstances, the value can even exceed $30 \%$.

The siliceous mineral source in Well TX-1 in the LCWF is determined by the same method used for Niutitang Formation's Well JY-2. Al, Fe, and Mn values in the segment where $\mathrm{Si}_{\text {ex }}$ exists were determined in the test and cast onto the triangular graph, as shown in Figure 7 . The results show that the silicon is mainly of biogenic origin, with a minor contribution from a mixed source. 


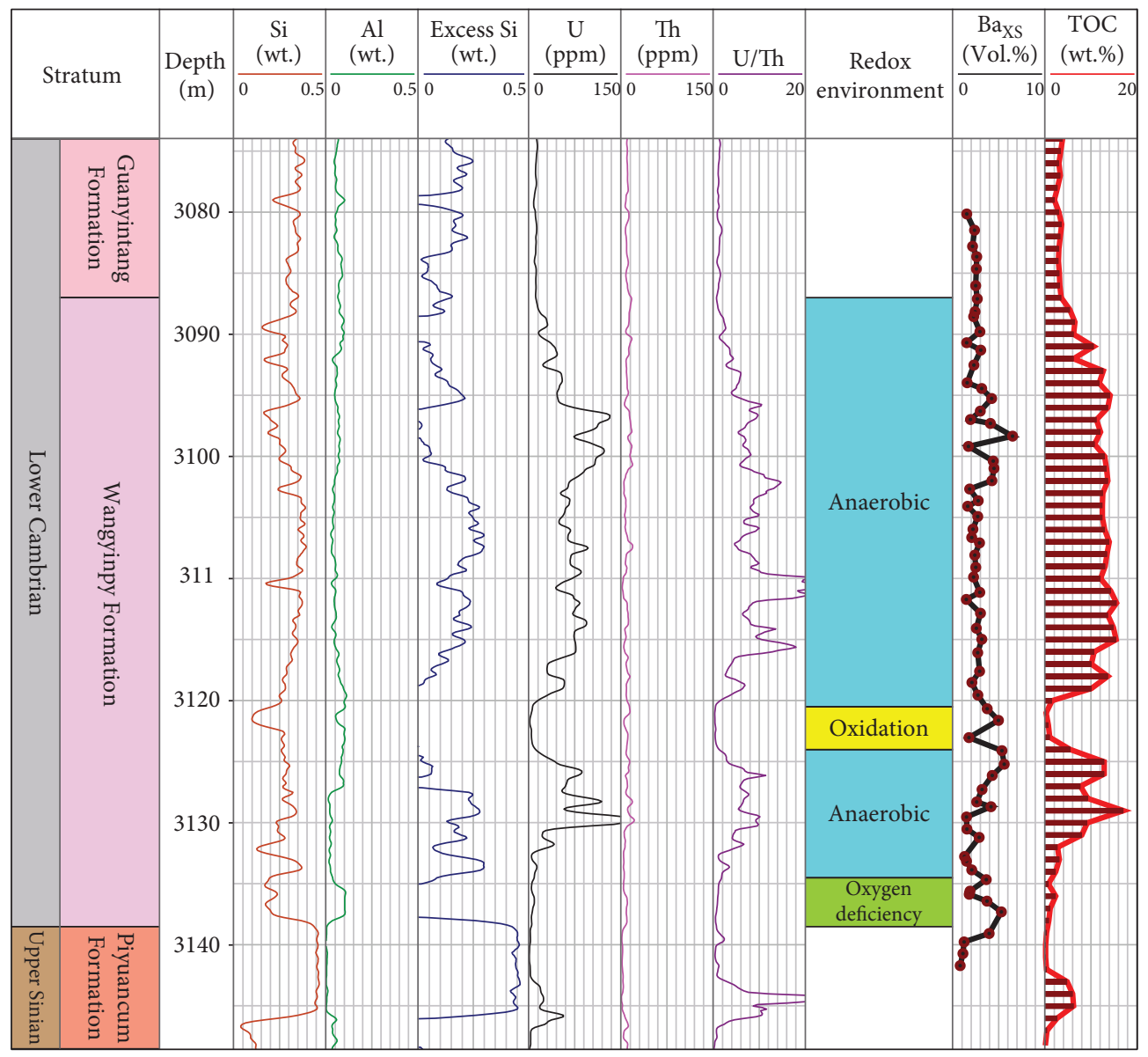

FIgURE 4: $\mathrm{Si}_{\mathrm{ex}}$, U/Th (index for redox environment), $\mathrm{Ba}_{\mathrm{xs}}$ (index for bioproductivity), and TOC content in Well JY-2 in the LCWF of the lower reaches of Yangtze region. The location of Well JY-2 is depicted in Figure 1.

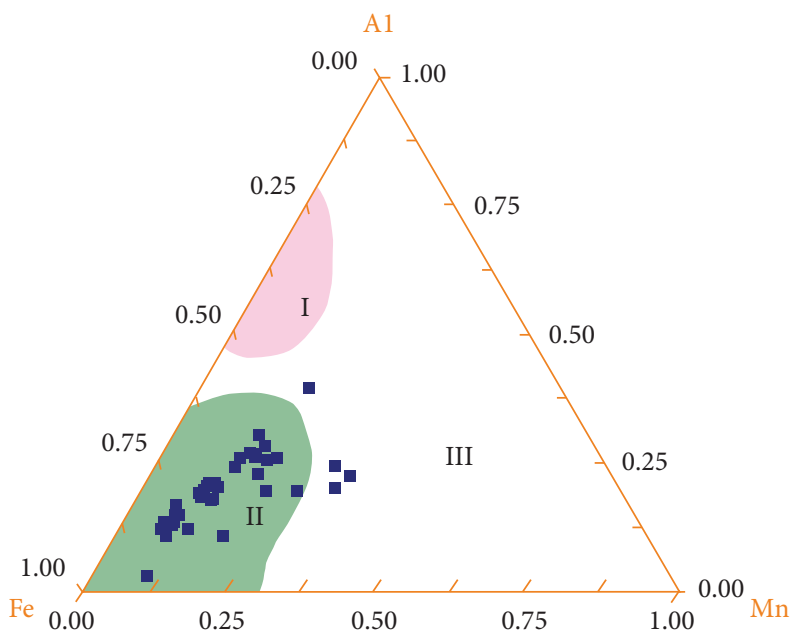

Figure 5: The Al-Fe-Mn triangular graph is adopted to demonstrate the source of siliceous minerals in Well JY-2's Si $i_{\text {ex }}$ segment in the LCWF. $\mathrm{Si}_{\mathrm{ex}}$ is discovered to be hydrothermal in origin. The location of Well JY-2 is shown in Figure 1. I indicates bioorigin; II indicates hydrothermal origin; and III indicates mixed origin. 


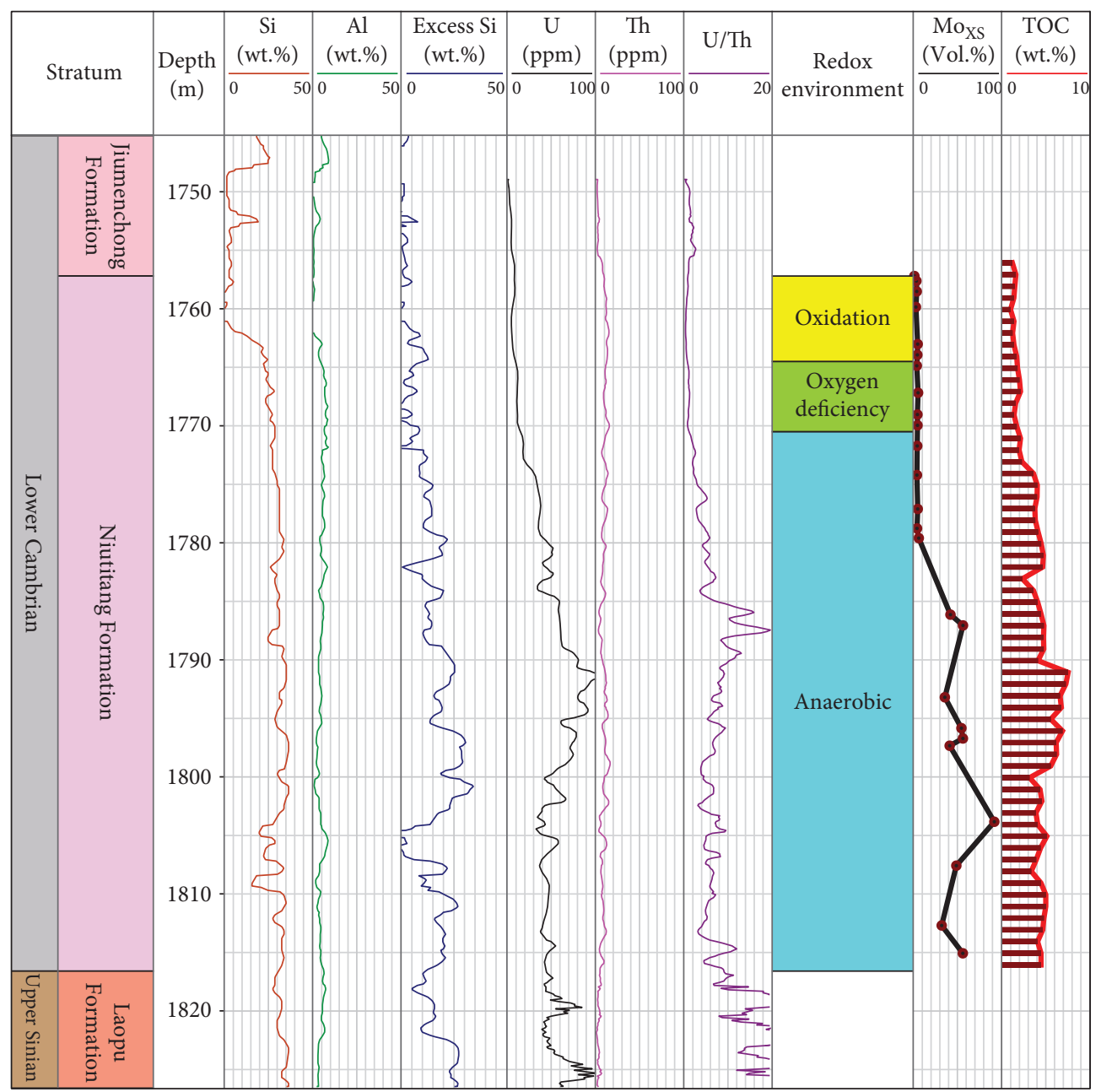

Figure 6: The content of $\mathrm{Si}_{\mathrm{ex}}$, U/Th (index for redox environment), $\mathrm{Ba}_{\mathrm{xs}}$ (index for bioproductivity), and TOC of Well TX-1 in the LCNF in the Yangtze region. The location of Well TX-1 is depicted in Figure 1.

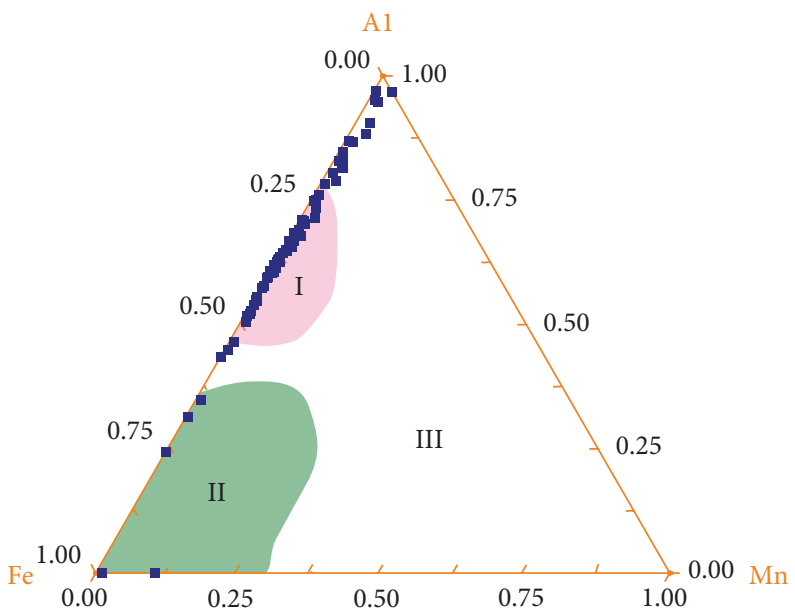

Figure 7: The Al-Fe-Mn triangular graph is adopted to explore the source of siliceous minerals in the Si $i_{\text {ex }}$ segment in Well TX-1 in the LCNF. The location of Well TX-1 is shown in Figure 1. I indicates bioorigin; II indicates hydrothermal origin; and III indicates mixed origin. 


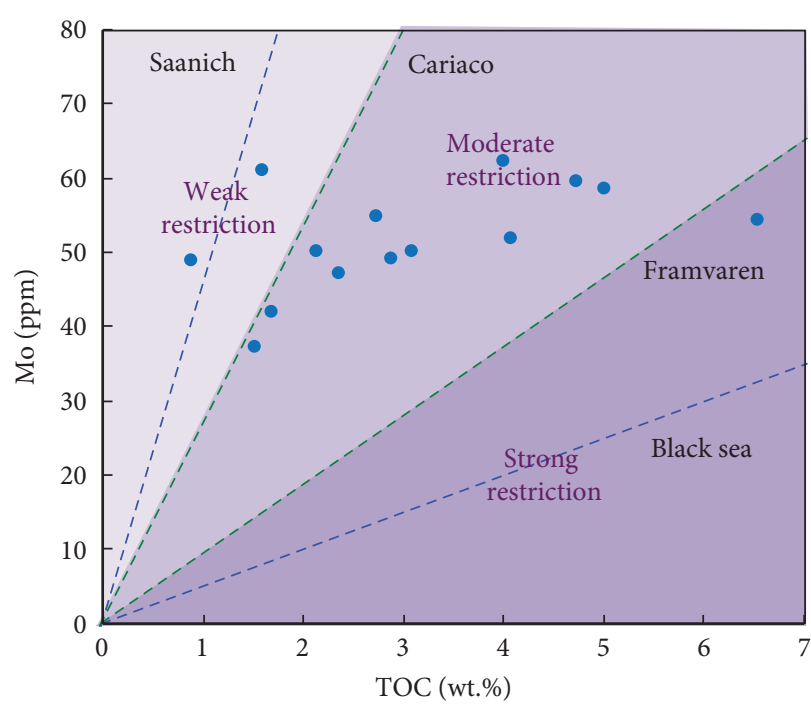

(a)

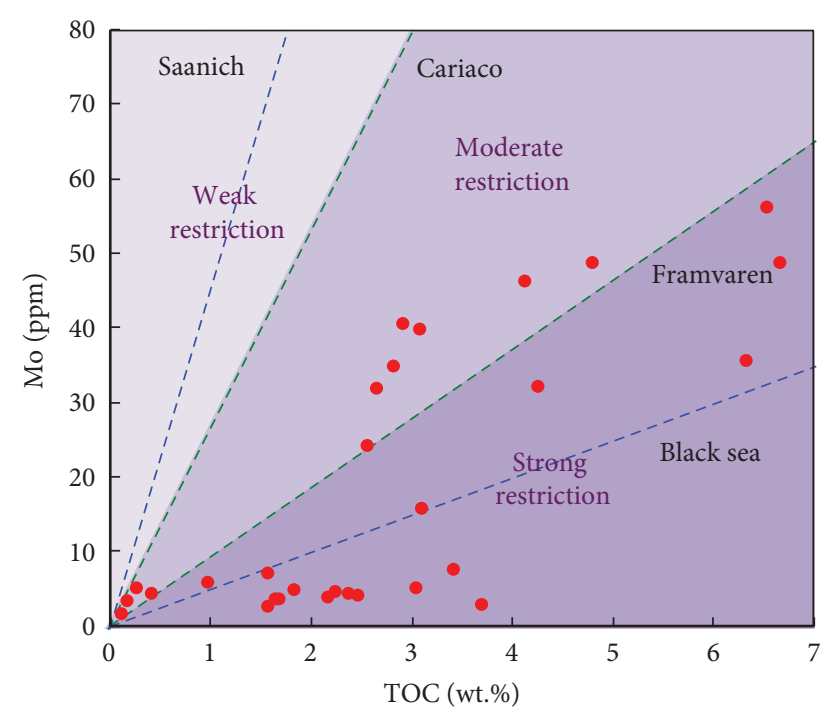

(b)

FIGURE 8: Well TX-1 in the Early Cambrian and nearby Taozichong outcrops, Zhalagou outcrops Mo-TOC content, and their relationship with waterbody closure. The Upper Niutitang Formation (a) and the Lower Niutitang Formation (b) during the sedimentary period.

\subsubsection{The Influence of Waterbody Closure Degree on En- richment of the Organic Matter Sediments}

(1) Determination of the Waterbody Closure Degree. As shown in Figure 7, Lower Cambrian shales in the Well TX-1 are mainly biogenic silica, and a small portion of them is silica of mixed biogenic and hydrothermal origin, which implies that the hydrothermal activity was weak in the Upper Yangtze region during the Early Cambrian, and hydrothermal activity did not play an important role in the enrichment of sedimentary organic matter in this region. The Mo and TOC contents reflect the closure degree of the waterbody [44-47]. Algeo and Lyons and Zhang et al. cast the statistics of 64 Lower Cambrian series, including Well TX-1, the Taozichong outcrops, and the Zhalagou outcrops nearby onto the block, respectively [48]. According to Figure 8, the statistics of the Lower Niutitang Formation were mostly concentrated in highly closed areas (Figure 8(b)), whereas those of the upper part were mostly concentrated in medium-closed counterparts (Figure 8(a)).

The analyses and conclusions of closure and hydrothermal activities were consistent with the structural background of the Early Cambrian area of the upper part of the Yangtze region. The Yangtze and Cathaysian Plates were separate from each other in the Early Cambrian, as shown in Figure 1. Well TX-1 and its periphery were located at the deep-water continental of the Upper Yangtze region, which were farther from the ancient land. However, the areas were close to the half-closed "gulf" surrounded by the shallow-water shelf and, therefore, had a relatively high closure. Besides, Well TX-1 and its periphery were distant from the convergence between the Yangtze Cathaysian Plates. Therefore, hydrothermal activities there were less intense.
(2) Influence of Waterbody Closure Degree on Redox Environment and Biological Productivity. Waterbody closure serves as the major cause of the distinction in the redox conditions and bioproductivity in the upper part of the Yangtze region and the LCNF. According to Cheng et al., when layering occurs in highly closed water, the upper part becomes oxic while the lower part becomes suboxic [48]. The upper water contained sufficient oxygen that promoted plankton propagation and growth, offering plenty of organic matter for the sedimentation [49-54]. Suboxic slowed the breakdown of organic matter sediments in lower parts, which facilitates the preservation of organic matter. Under low closure degrees, on the other hand, the bottom water gradually converges with the warm water at the top, damaging the original environment [24,55-59]. Meanwhile, there was less sedimentary organic matter with lower abundance as they further underwent dilution and oxidative decomposition [60-63].

According to the analysis of Well TX-1's statistics in Figure 6, the waterbody closure of the Lower Niutitang Formation was strong during the sedimentary period, characterizing high U/Th values (4 20) in the lower part of the redox environment where the water had strong reducibility. As the height rose, the value decreased to $0 \sim 4$, showing the conversion from oxygen-deficient to the oxygen-lean environment and eventually oxidizing environment. Meanwhile, $\mathrm{Mo}_{\mathrm{xs}}$, the index characterizing bioproductivity, decreased as heights increased. This was also true for the excess siliceous mineral content.

(3) Influence of Waterbody Closure Degree on the TOC Content. The level of closure influences water's redox environment and bioproductivity, further affecting the TOC content in shales. According to Figure 6, TOC content could amount to $3 \% \sim 7.5 \%$ in the Lower LCNF, where waterbody 


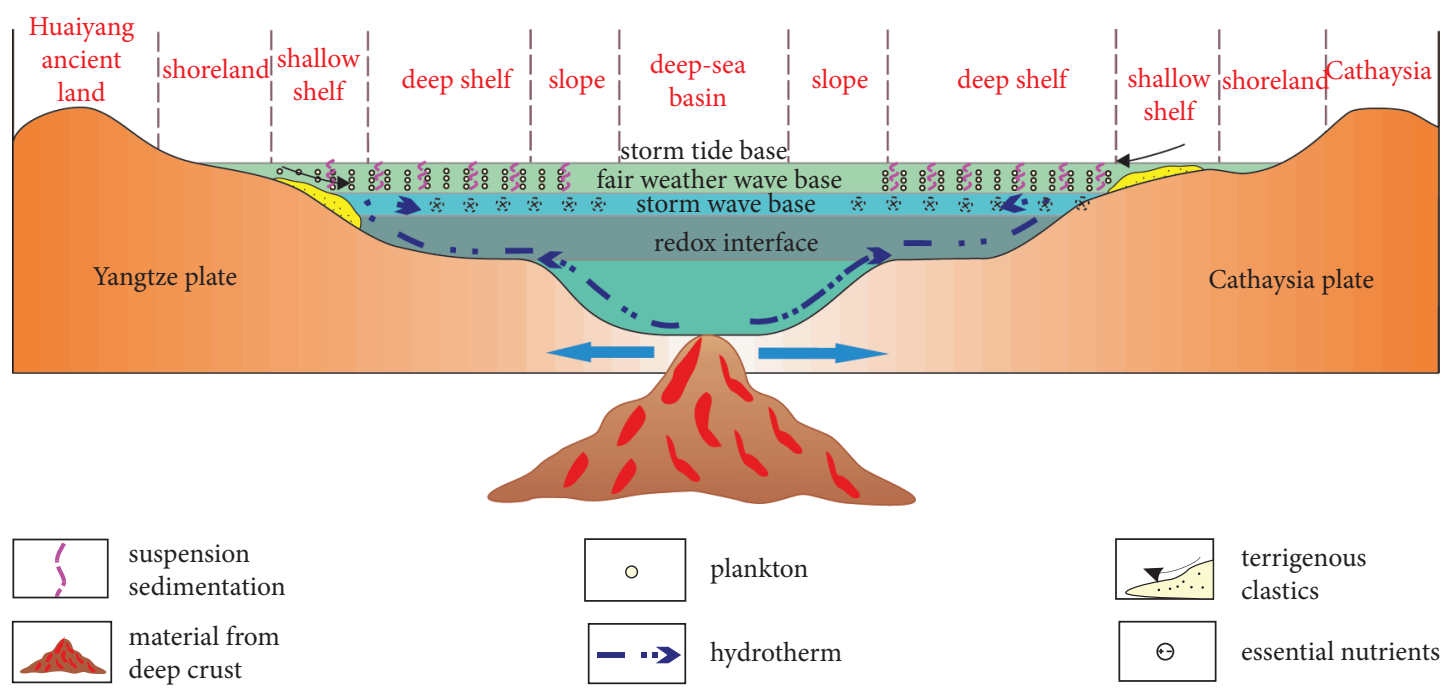

(a)
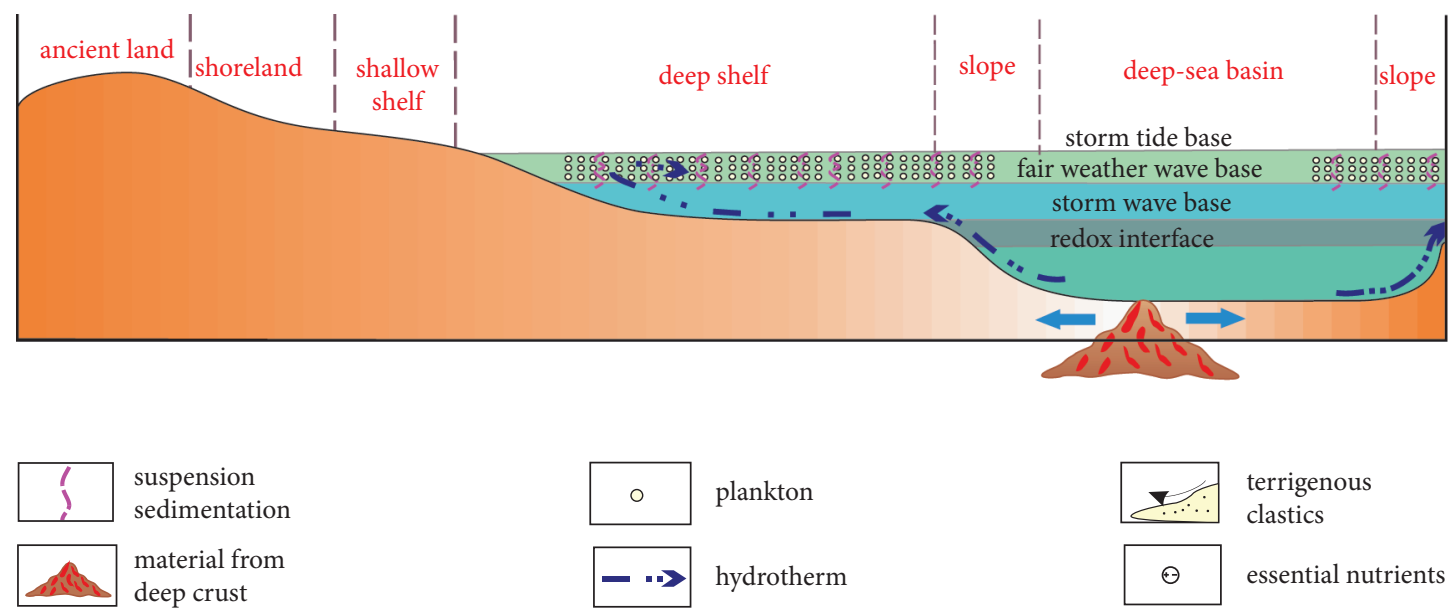

(b)

FIGURE 9: Enrichment patterns of organic matter sediments of the Lower Yangtze (a) and Upper Yangtze (b) during the Early Cambrian (adapted from [64-66]).

closure was strong, while, in the Upper LCNF, the content was lower with weak waterbody closure, ranging from $1 \%$ to $2 \%$.

\subsection{Enrichment Patterns of Organic Matter Sediments in the Lower and Upper Yangtze Areas in the Early Cambrian}

4.5.1. The Lower Yangtze Region in the Early Cambrian. According to Figure 9(a), in the Early Cambrian, the hydrothermal fluids with nutrition from the deep crust moved into the Oceanic Basin in the Lower Yangtze region because of extension tectonics of the Yangtze and Cathaysian Plates. The upwelling current brought fluids to the continental area in the end. For one thing, the hydrothermal fluids were mixed with nutritive salt-rich surface water, promoting plankton propagation and growth and enhancing bioproductivity. The fluids at the bottom of the waterbody, for another, created a reducible environment, thus facilitating the preservation of organic matter in the primitive sediment. Both were beneficial to sediment enrichment.
4.5.2. The Upper Yangtze Region in the Early Cambrian. The Early Cambrian Upper Yangtze region was located far from the convergence of the Yangtze and the Cathaysian Plates, as shown in Figure 9(b). As a result, hydrothermal activities there were weaker than those in the lower counterpart. The deep-water continent in the Upper Yangtze Area neared the half-closed "gulf" surrounded by the shallowwater continent. As a result, the waterbody became more sealed off, and layering occurred in the Lower Niutitang Formation. On the top, the abundant oxygen promoted planktons' fast propagation. At the bottom, the hypoxic reduction environment was conducive to preserving the organic matter sediments from the upper layers, facilitating its enrichment. In the Upper Niutitang Formation, the waterbody was less enclosed during the sedimentary period, and thereby the water from different layers mixed up, resulting in the bioproductivity decrease. Furthermore, the reducibility of the waterbody at the bottom also decreased, which impeded the conservation of the sedimentary organic matter. 


\section{Conclusions}

The Lower Cambrian marine shales in South China's Yangtze region were studied in this paper. The influences of organic matter on gas content and the enrichment patterns of organic matter sediments are studied in Well JY-2 in the Lower Yangtze Region of LCWF and Well TX-1 in the Upper Yangtze region of LCNF. The conclusions are as follows:

(1) The TOC content of shales controls the free and adsorbed gas contents. The primary source of shale gas is organic pores. The pore development of organic matter is high in number and roundness, with "small pores nesting in the large pores" and good connectivity.

(2) In the Lower Cambrian shales of the lower reaches of the Yangtze region, other than the common continental clastic origin, the rest of siliceous minerals are hydrothermal originally. Hydrothermal activities were common in the lower reaches of the Yangtze region near the confluence of the Yangtze and Cathaysian Plates. These activities increased the reducibility of the waterbody's bottom and the bioproductivity of its surface, further facilitating the enrichment of the organic matter sediments.

(3) In the Upper counterpart, besides the continental clastic origin, most of the siliceous minerals were formed through biological activities, with only a few having both biological and hydrothermal origins. The Upper Yangtze region was far from the convergence of the Yangtze and Cathaysian Plates and was close to the half-closed "gulf" surrounded by the shallow-water shelf. Relatively strong waterbody closure gave rise to the layering phenomenon. There was sufficient oxygen on the top, leading to high bioproductivity, while the reducibility was strong at the bottom, promoting the sedimentation of the organic matter.

\section{Data Availability}

Some of the data are contained in a published source cited in the references. All the data in this paper are accessible to the readers.

\section{Additional Points}

Highlights. (1) The TOC content controls the free and adsorbed gas contents. The shale gas mainly occurs in organic pores and is developed in large numbers, with "small pores nesting in big pores," showing the characteristics of high roundness and good connectivity. (2) Lower Yangtze region's closeness to plate boundaries induced intensive hydrothermal activities in the Early Cambrian period, thus affecting organic matter's enrichment. (3) Upper Yangtze region was farther from plate boundaries but close to the semiclosed "gulf." Thus, the enclosed waterbody played the leading role in organic matter's enrichment, while hydrothermal activities were the secondary influencing factor.

\section{Conflicts of Interest}

The authors declare that there are no conflicts of interest with respect to the results of this paper.

\section{Acknowledgments}

This study was supported by the National Natural Science Foundation of China (nos. 42102192, 42130803, and 42072174), the Open Fund of Key Laboratory of Tectonics and Petroleum Resources (China University of Geosciences), Ministry of Education, Wuhan (TPR-2020-07), the Fundamental Research Funds for the Central Universities (35832019035), the Open Funds from the State Key Laboratory of Petroleum Resources and Prospecting (PRP/open-2107), the Open Funds from the State Key Laboratory of Shale Oil and Gas Enrichment Mechanisms and Effective Development (G5800-20-ZS-KFGY012), and the Science and Technology Cooperation Project of the CNPC-SWPU Innovation Alliance.

\section{References}

[1] D. Dong, Y. Wang, X. Li et al., "Breakthrough and prospect of shale gas exploration and development in China," Natural Gas Industry, vol. 36, no. 1, pp. 19-32, 2016.

[2] T. Guo, "Key geological issues and main controls on accumulation and enrichment of Chinese shale gas," Petroleum Exploration and Development, vol. 43, no. 3, pp. 317-326, 2016.

[3] X. Guo, D. Hu, Z. Wei, Y. Li, and X. Wei, "Discovery and exploration of fuling shale gas field," China Petroleum Exploration, vol. 21, no. 3, pp. 24-37, 2016.

[4] Z. Gao and Q. Hu, "Pore structure and spontaneous imbibition characteristics of marine and continental shales in China," AAPG Bulletin, vol. 102, no. 10, pp. 1941-1961, 2018.

[5] V. Agrawal and S. Sharma, "Testing utility of organogeochemical proxies to assess sources of organic matter, paleoredox conditions, and thermal maturity in mature marcellus shale," Frontiers in Energy Research, vol. 6, p. 42, 2018.

[6] Z. Xi, S. Tang, S. Zhang, and Y. Ye, "Factors controlling organic matter accumulation in the wufeng-longmaxi formations in northwestern hunan province: insights from major/trace elements and shale composition," Energy \& Fuels, vol. 34, no. 4, pp. 4139-4152, 2020.

[7] Y. Wang, S. Xu, F. Hao et al., "Geochemical and petrographic characteristics of Wufeng-Longmaxi shales, Jiaoshiba area, southwest China: implications for organic matter differential accumulation," Marine and Petroleum Geology, vol. 102, pp. 138-154, 2019.

[8] C. Yan, Z. Jin, J. Zhao, W. Du, and Q. Liu, "Influence of sedimentary environment on organic matter enrichment in shale: a case study of the Wufeng and Longmaxi Formations of the Sichuan Basin, China," Marine and Petroleum Geology, vol. 92, pp. 880-894, 2018.

[9] Y. Ma, Y. Lu, X. Liu, G. Zhai, Y. Wang, and C. Zhang, "Depositional environment and organic matter enrichment of the lower Cambrian Niutitang shale in western Hubei Province, South China," Marine and Petroleum Geology, vol. 109, pp. 381-393, 2019.

[10] W. Xia, B. Yu, and M. Sun, "Depositional setting and enrichment mechanism of organic matter of the black shales of 
Niutitang Formation at the bottom of lower cambrian, in well Yuke1, southeast chongqing," Acta Geologica Sinica-English Edition, vol. 35, no. 2, pp. 70-80, 2015.

[11] K. Zhang, Z. Jiang, L. Yin et al., "Controlling functions of hydrothermal activity to shale gas content-taking lower Cambrian in Xiuwu Basin as an example," Marine and $\mathrm{Pe}$ troleum Geology, vol. 85, pp. 177-193, 2017.

[12] K. Zhang, Z. Li, S. Jiang et al., "Comparative analysis of the siliceous source and organic matter enrichment mechanism of the upper ordovician-lower silurian shale in the upper-lower yangtze area," Minerals, vol. 2018, no. 8, p. 283, 2018.

[13] Z. Qiu and C. Zou, "Unconventional petroleum sedimentology: connotation and prospect," Acta Sedimentologica Sinica, vol. 38, no. 1, pp. 1-29, 2020.

[14] W. Xia, B. Yu, and M. Sun, "Depositional setting and enrichment mechanism of organic matter of the black shales of niutitang formation at the bottom of lower cambrian,in well yuke1, southeast chongqing," Journal of Mineralogy and Petrology, vol. 35, no. 2, pp. 70-80, 2015, in Chinese.

[15] Y. Zhang, Z. He, B. Gao, and Z. Liu, "Sedimentary environment of the Lower Cambrian organic-rich shale and its influence on organic content in the Upper Yangtze," Petroleum Geologye Experiment, vol. 39, no. 2, pp. 154-161, 2017, in Chinese.

[16] Z. Qiu, B. Lu, Z. Chen et al., "Discussion of the relationship between volcanic ash layers and organic enrichment of black shale: a case study of the wufeng-longmaxi gas shales in the sichuan basin," Acta Sedimentologica Sinica, vol. 37, no. 6, pp. 1296-1308, 2019, in Chinese.

[17] Q. Zhang, J. Wang, Q. Yu et al., “The silicon source and sedimentary environment of the lower silurian longmaxi formation in yanyuan basin, western edge of the yangtze platform," Geological Review, vol. 64, no. 3, pp. 610-622, 2018.

[18] H. Holdaway and C. Clayton, "Preservation of shell microstructure in silicified brachiopods from the upper cretaceous Wilmington sands of Devon," Geological Magazine, vol. 119, pp. 371-382, 1985.

[19] K. H. Wedepohl, "Environmental influences on the chemical composition of shales and clays," Physics and Chemistry of the Earth, vol. 8, pp. 307-333, 1971.

[20] M. Adachi, K. Yamamoto, and R. Sugisaki, "Hydrothermal chert and associated siliceous rocks from the Northern Pacific: their geological significance as indication of ocean ridge activity," Sedimentary Geology, vol. 47, no. 1, pp. 125-148, 1986.

[21] K. Yamamoto, "Geochemical characteristics and depositional environments of cherts and associated rocks in the Franciscan and Shimanto Terranes," Sedimentary Geology, vol. 52, no. 12, pp. 65-108, 1987.

[22] M. Zhu, J. Zhang, M. Steiner, A. Yang, G. Li, and B. Erdtmann, "Sinian-Cambrian stratigraphic framework for shallow- to deep-water environments of the Yangtze platform: an integrated approach," Progress in Natural Science, vol. 13, no. 12, pp. 951-960, 2003.

[23] M. Zhu, L. Babcock, and S. Peng, "Advances in Cambrian stratigraphy and paleontology: integrating correlation techniques, paleobiology, taphonomy and paleoenvironmental reconstruction," Palaeoworld, vol. 15, no. 3/4, pp. 217-222, 2006.

[24] Z. Liu, B. Gao, Y. Zhang, W. Du, D. Feng, and H. Nie, “Types and distribution of the shale sedimentary facies of the Lower cambrian in upper Yangtze area, South China," Petroleum Exploration and Development, vol. 44, no. 1, pp. 21-31, 2017, in Chinese.
[25] Y. Zhang, Z. He, S. Jiang et al., "Marine redox stratification during the early Cambrian (ca. 529-509 Ma) and its control on the development of organic-rich shales in Yangtze platform," Geochemistry, Geophysics, Geosystems, vol. 18, no. 6, pp. 2354-2369, 2017.

[26] J. Wang and Z. Li, "History of neoproterozoic rift basins in south China: implications for rodinia break-up," Precambrian Research, vol. 122, no. 1/4, pp. 141-158, 2003.

[27] R. Wang, W. Ding, D. Gong, J. Leng, X. Wang, and S. Yin, "Logging evaluation method and its application for total organic carbon content in shale: a case study on the lower cambrian Niutitang formation in Cengong block, Guizhou Province," Journal of China Coal Society, vol. 40, no. 12, pp. 2874-2883, 2015, in Chinese.

[28] R. Wang, J. Leng, W. Ding, D. Long, F. Li, and Y. Sun, "Logging identification for the lower cambrian niutitang shale reservoir in the upper yangtze region, China: a case study of the Cengong block, Guizhou province," Journal of Natural Gas Geoscience, vol. 26, no. 12, pp. 2395-2407, 2015, in Chinese.

[29] R. Wang, W. Ding, D. Gong et al., "Gas preservation conditions of marine shale in northern Guizhou area: a case study of the lower cambrian Niutitang Formation in the Cen'gong block, Guizhou Province," Oil \& Gas Geology, vol. 37, no. 1, pp. 45-55, 2016, in Chinese.

[30] R. Wang, W. Ding, Y. Zhang et al., "Analysis of developmental characteristics and dominant factors of fractures in lower cambrian marine shale reservoirs: a case study of Niutitang formation in Cen'gong block, southern China," Journal of Petroleum Science and Engineering, vol. 138, pp. 31-49, 2016.

[31] R. Wang, D. Gong, J. Leng et al., "Developmental characteristics of the lower cambrian Niutitang shale reservoir in Northern Guizhou area: a case study in the Cengong block," Earth Science Frontiers, vol. 24, no. 6, pp. 286-299, 2017, in Chinese.

[32] B. Jones and D. Manning, "Comparison of geochemical indices used for the interpretation of palaeoredox conditions in ancient mudstones," Chemical Geology, vol. 111, no. 1/4, pp. 111-129, 1994.

[33] T. J. Algeo, K. Kuwahara, H. Sano et al., "Spatial variation in sediment fluxes, redox conditions, and productivity in the Permian-Triassic Panthalassic Ocean," Palaeogeography, Palaeoclimatology, Palaeoecology, vol. 308, no. 1, Article ID 65e83, 2011.

[34] S. R. Taylor and S. M. McLennan, The Continental Crust: Its Composition and Evolution, Blackwell Scientific Publications, Oxford, UK, 1985.

[35] K. Boström, T. Kraemer, and S. Gartner, "Provenance and accumulation rates of opaline silica, $\mathrm{Al}, \mathrm{Ti}, \mathrm{Fe}, \mathrm{Mn}, \mathrm{Cu}, \mathrm{Ni}$ and Co in pacific pelagic sediments," Chemical Geology, vol. 11, no. 2, pp. 123-148, 1973.

[36] R. W. Murray, M. R. Buchholtz Ten Brink, D. C. Gerlach, G. P. Russ, and D. L. Jones, "Rare earth, major, and trace elements in chert from the franciscan complex and monterey group, California: assessing REE sources to fine-grained marine sediments," Geochimica et Cosmochimica Acta, vol. 55, no. 7, pp. 1875-1895, 1991.

[37] J. Liu and M. Zheng, "Geochemistry of hydrothermal sedimentary silicalite," Acta Geological Sichuan, vol. 13, no. 2, pp. 110-118, 1993, in Chinese.

[38] C. Zou, D. Dong, Y. Wang et al., "Shale gas in China: characteristics, challenges and prospects (I)," Petroleum Exploration and Development, vol. 42, no. 6, pp. 689-701, 2015, in Chinese. 
[39] K. Zhang, Y. Song, S. Jiang et al., "Mechanism analysis of organic matter enrichment in different sedimentary backgrounds: a case study of the lower cambrian and the upper ordovician-lower silurian, in Yangtze region," Marine and Petroleum Geology, vol. 99, pp. 488-497, 2019.

[40] X. Sun, J. Chen, W. Liu, S. Zhang, and D. Wang, "Hydrothermal venting on the seafloor and formation of organic-rich sediments: evidence from the neoproterozoic xiamaling formation, North China," Geological Review, vol. 49, no. 6, pp. 588-595, 2003, in Chinese.

[41] X. Sun, J. Chen, J. Zheng, and W. Liu, "Geochemical characteristics of organic matter-rich sedimentary strata in lower Cambrian, Tarim Basin and its origins," Acta Sedimentologica Sinica, vol. 22, no. 3, pp. 548-552, 2004, in Chinese.

[42] W. Zhang, H. Yang, L. Xie, and Y. Yang, "Lake-bottom hydrothermal activities and their influences on the high-quality source rock development: a case from Chang 7 source rocks in Ordos Basin, China," Petroleum Exploration and Development, vol. 37, no. 4, pp. 424-429, 2010, in Chinese.

[43] M. Halbach, A. Koschinsky, and P. Halbach, "Report on the discovery of gallionella ferruginea from an active hydrothermal field in the deep sea," InterRidge News, vol. 10, no. 1, pp. 18-20, 2001.

[44] T. Algeo and T. Lyons, "Mo-total organic carbon covariation in modern anoxic marine environments: implications for analysis of paleoredox and paleohydrographic conditions (PA 1016)," Paleoceanography, vol. 21, p. 23, 2006.

[45] J. Yang, D. Wang, J. Mao, Z. Zhang, Z. Zhang, and Z. Wang, "The petrochemical research method for silicalite and its application to the "jingtieshan type" iron deposits," Acta Petrologica et Mineralogical, vol. 18, no. 2, pp. 108-118, 1999, in Chinese.

[46] Y. Wu, T. Fan, S. Jiang, and X. Yang, "Lithofacies and sedimentary sequence of the lower cambrian niutitang shale in the upper yangtze platform, south China," Journal of Natural Gas Science and Engineering, vol. 43, pp. 124-136, 2017.

[47] K. Zhang, J. Peng, X. Wang et al., "Effect of organic maturity on shale gas genesis and pores development: a case study on marine shale in the upper Yangtze region, South China," Open Geosciences, vol. 12, no. 1, pp. 1617-1629, 2020.

[48] L. Cheng, Y. Wang, H. Chen, Y. Wang, and Y. Zhong, "Sedimentary and burial environment of black shales of Sinian to early palaeozoic in upper Yangtze region," Acta Petrologica Sinica, vol. 29, no. 8, pp. 2906-2912, 2013.

[49] J. Chen, S. Zhang, S. Sun, and Q. Wu, "Main factors influencing marine carbonate source rock formation," Acta Geologica Sinica-English Edition, vol. 80, no. 3, pp. 467-472, 2006.

[50] K. Zhang, Z. Jiang, X. Xie et al., "Lateral percolation and its effect on shale gas accumulation on the basis of complex tectonic background," Geofluids, vol. 2018, Article ID 5195469, 11 pages, 2018.

[51] K. Zhang, Y. Song, C. Jia et al., "Vertical sealing mechanism of shale and its roof and floor and effect on shale gas accumulation, a case study of marine shale in Sichuan basin, the Upper Yangtze area," Journal of Petroleum Science and Engineering, vol. 175, pp. 743-754, 2019.

[52] K. Zhang, Y. Song, S. Jiang et al., "Shale gas accumulation mechanism in a syncline setting based on multiple geological factors: an example of southern Sichuan and the Xiuwu Basin in the Yangtze Region," Fuel, vol. 241, pp. 468-476, 2019.

[53] K. Zhang, C. Jia, Y. Song et al., "Analysis of Lower Cambrian shale gas composition, source and accumulation pattern in different tectonic backgrounds: a case study of Weiyuan Block in the Upper Yangtze region and Xiuwu Basin in the Lower Yangtze region," Fuel, vol. 263, Article ID 115978, 2020.

[54] K. Zhang, Y. Song, S. Jiang et al., "Accumulation mechanism of marine shale gas reservoir in anticlines: a case study of the southern Sichuan Basin and Xiuwu Basin in the Yangtze region," Geofluids, vol. 2019, Article ID 5274327, 14 pages, 2019.

[55] J. Peng, J. Liu, Y. Wang, and J. Liu, "Origin and controlling factors of chlorite coatings-an example from the reservoir of T3x Group of the Baojie area, Sichuan Basin, China," Petroleum Science, vol. 6, no. 4, pp. 376-382, 2009.

[56] J. Peng, H. Zhang, and X. Lin, "Study on characteristics and genesis of botryoidal dolostone of the upper sinian dengying formation: a case study from Hanyuan region, Sichuan, China," Carbonates and Evaporites, vol. 3, pp. 1-15, 2017.

[57] X. Chen, L. Chen, X. Guo, and C. Wang, "Geochemical characteristics of shale gas in the silurian longmaxi formation, Jiaoshiba area, southeast sichuan basin, China," Energy \& Fuels, vol. 33, pp. 8045-8054, 2019.

[58] S. Jiang, L. Chen, Y. Wu, Z. Jiang, and E. McKenna, "Hybrid plays of upper triassic Chang7 lacustrine source rock interval of yanchang formation, ordos basin, China," Journal of Petroleum Science and Engineering, vol. 159, pp. 182-196, 2017.

[59] W. Ji, Y. Song, Z. Rui, M. Meng, and H. Huang, "Pore characterization of isolated organic matter from high matured gas shale reservoir," International Journal of Coal Geology, vol. 174, pp. 31-40, 2017.

[60] W. Ji, F. Hao, H.-M. Schulz, Y. Song, and J. Tian, "The architecture of organic matter and its pores in highly mature gas shales of the Lower Silurian Longmaxi Formation in the Upper Yangtze Platform, south China," AAPG Bulletin, vol. 103, no. 12, pp. 2909-2942, 2019.

[61] X. Zhao, K. Qi, L. Liu, C. Gong, and W. D. Mccaffrey, "Development of a partially-avulsed submarine channel on the Niger Delta continental slope: architecture and controlling factors," Marine and Petroleum Geology, vol. 95, pp. 30-49, 2018.

[62] X. Zhao, M. Li, K. Qi et al., "Development of a distinct submarine depositional system on a topographically complex Niger Delta slope," Geological Journal, vol. 55, no. 5, pp. 3732-3747, 2020.

[63] X. Zhao, K. Qi, M. Patacci, C. Tan, and T. Xie, "Submarine channel network evolution above an extensive mass-transport complex: a 3D seismic case study from the Niger delta continental slope," Marine and Petroleum Geology, vol. 104, pp. 231-248, 2019.

[64] K. Zhang, J. Peng, W. Liu et al., "The role of deep geofluids in the enrichment of sedimentary organic matter: a case study of the Late Ordovician-Early Silurian in the upper Yangtze region and early Cambrian in the lower Yangtze region, south China," Geofluids, vol. 2020, Article ID 8868638, 12 pages, 2020.

[65] R. S. Awan, C. Liu, H. Gong, C. Dun, C. Tong, and L. G. Chamssidini, "Paleo-sedimentary environment in relation to enrichment of organic matter of Early Cambrian black rocks of Niutitang Formation from Xiangxi area China," Marine and Petroleum Geology, vol. 112, Article ID 104057, 2020.

[66] Z. Liu, D. Yan, X. Du, and S. Li, "Organic matter accumulation of the early Cambrian black shales on the flank of Micangshan-Hannan uplift, northern upper Yangtze Block, South China," Journal of Petroleum Science and Engineering, vol. 2021, p. 200, Article ID 108378, 2021. 